\title{
An Illustrated Diagnostic Key of the Species in the Venezuelan Clade of ESPELETIa (ASTERACEAE).
}

\author{
JESÚS MAVÁREZ ${ }^{1,2}$
}

Footnotes start here

I am very grateful to Angel Fernández, director of the Instituto Venezolano de Investigaciones Científicas herbarium (IVIC), and Serge Aubert (1966--2015), director of Station Alpine Joseph Fourier (France) who provided invaluable assistance in the field during the numerous fieldtrips to the páramos of Venezuela. They participated actively in most of the tests of key performance on living plants. Unfortunately, Serge passed away too soon to see this work finished.

I am also grateful for the help provided during fieldwork by Benito Briceño, Gilberto Morillo, John Parra, Luis “Kicke” Gámez, Reina Gonto, Sébastien Lavergne, Susana González and Thibaud Syre. Logistic support was provided by the Centro de Investigaciones de Astronomía (CIDA), Dirección Regional Inparques Mérida and Teleférico Mukumbarí. I am also grateful to the staff in herbarium IVIC for the support provided for this work and for the tests of key performance of dry samples. Université Grenoble Alpes and the CNRS provided funding (PEPS and OSUG grants).

${ }^{1}$ Laboratoire d'Écologie Alpine, UMR UGA-USMB-CNRS 5553 Université Grenoble Alpes, 38000 Grenoble, France.

${ }^{2}$ Address for correspondence: LECA, BP 53, 2233 rue de la Piscine, 38041 Grenoble Cedex 9, France; jesus.mavarez@,univ-grenoble-alpes.fr

Footnotes end here-

Abstract. An illustrated key is presented for the species in the Venezuelan clade of Espeletia (Asteraceae), based on herbarium specimens, virtual herbaria and fresh samples from field collections. The fifty-four Espeletia species in this clade are documented: (i) 48 entirely endemic to the Venezuelan Andes, (ii) two found as well in the Venezuelan Cordillera de la Costa, the eastern section of the Colombian Cordillera Oriental and the Sierra Nevada de Santa Marta, and (iii) four endemic to eastern Colombian Cordillera Oriental and Sierra de Perijá. Schematic representations of leaves of all species are provided, including important 
diagnostic characters such as length-to-width ratios, and the shape, density or angles of secondary nerves. Additional diagnostic characters are also described or illustrated for some species, such as the type of indumentum on leaves, the structure of the inflorescence, the size of the capitulum, and the colour of ray ligules. The key has been shown to allow identification of species using both herbarium samples and fresh material, and given the predominant use of vegetative characters it is also useful on some monocarpic rosettes species that are frequently found in the vegetative stage.

Keywords. Andes, Asteraceae, caulescent rosette, Cordillera de Mérida, Espeletia, frailejón, páramo, Venezuela.

The plants in the genus Espeletia Mutis ex Bonpl (Humboldt and Bonpland, 1809) represent the best example of taxonomic, morphological and ecological diversification in the tropical high-elevation grassland ecosystem of the Northern Andes known as páramo (Diazgranados, 2012; Cuatrecasas, 2013; Diazgranados and Barber, 2017; Pouchon et al., 2018; Mavárez, 2019). The genus evolved from a single ancestor quite recently, about $2.5 \mathrm{My}$ ago (Pouchon et al. 2018), after the final uplift of the Northern Andes that facilitated the environmental conditions for the páramo habitat (Hooghiemstra et al., 2006; Torres et al., 2013). The ca. 140 Espeletia species are distributed phylogenetically in two major groups (Diazgranados and Barber, 2017; Pouchon et al., 2018; Mavárez, 2019): (i) a north-eastern clade of 54 species, a.k.a. "Venezuelan clade", almost entirely restricted to the Venezuelan Cordillera de Mérida, with some species found in the Venezuelan Cordillera de la Costa, the eastern section of the Colombian Cordillera Oriental, the Sierra de Perijá and the Sierra Nevada de Santa Marta, and (ii) a south-western clade of $c a .80$ species, a.k.a. "Colombian clade", distributed across the Colombian Andes, the Sierra de Perijá and northern Ecuador. The Venezuelan clade is morphologically more diverse, since it includes shrubs and unbranched, dichotomous or profusely branched trees, and also monocarpic and polycarpic rosettes that can be sessile, short-branched or unbranched. The Colombian clade, richer in species, is composed exclusively by polycarpic rosettes, almost all of them unbranched, plus one species that always is profusely branched (Mavárez and Becerra, 2019) and two that can occasionally be sparsely branched (Cuatrecasas, 1996).

The identification of Espeletia species can sometimes be a real challenge, most particularly when attempted directly in the field. An important number of taxa are indeed very similar morphologically, differing mainly on quantitative traits associated with the shape and 
size of leaves, inflorescences and capitula. On the other hand, sympatry is also particularly common among members of this genus and it is not unusual to find several species living near each other in some locations, as for instance in Sierra de la Culata, Venezuela, where up to eleven rosette species can be found in close sympatry (Mavárez pers. obs.). Furthermore, inter-specific hybridisation can be relatively frequent between certain species pairs, contributing thereby to the morphological variation observed within some taxa (Berry et al., 1988; Pouchon et al., 2018; Mavárez, 2019). Researchers studying Espeletia are therefore often confronted to situations in which groups of morphologically similar and closely-related species in this genus coexist in sympatry and, in some cases, hybridise. This identification challenge can receive an additional difficulty in Venezuela, where about half of the rosette species are monocarpic, spending many years in a vegetative state before flowering for a few days or weeks, after which they die. The identification of these taxa must often rely on vegetative traits of the rosettes, yet available identification keys for these plants usually depend strongly on reproductive traits (Cuatrecasas, 1996, 2013).

In this work I present an illustrated diagnostic key for the 54 species in the Venezuelan clade of Espeletia (Mavárez, 2019), leaving the analysis of the species in the Colombian clade for another work to be presented in the near future. The key is mainly aimed at the identification of live plants directly in the field, but several of the diagnostic traits used can also be retrieved from dry samples, so that they key may be used as well to identify herbarium specimens.

\section{Materials AND Methods}

Samples: the key is based on the analysis of 2264 samples reliably identified to the species level: 1450 samples deposited in herbaria B, BC, BR, COL, F, G, GH, HAL, IVIC, K, LD, MER, MERF, MO, MY, NY, P, S, U, US and W (Thiers, 2019), and 814 plants identified during fieldwork by the author and some colleagues ( 250 of which are now deposited at herbarium IVIC). These samples include all 54 species currently known to belong to the Venezuelan clade of Espeletia and thirteen inter-specific hybrid taxa that have received binomials in the past (Mavárez, 2019). However, hybrid taxa will not be treated in this key.

Morphological characters: The key used the inter-specific variation observed at several diagnostic macroscopic morphological attributes of the plants' stem, leaves, 
inflorescences and capitula, all of which can be easily measured on both living plants and herbarium samples without need for sophisticated equipment:

a) Growth-form. Habitus (tree or rosette), type of stem branching (branched or unbranched, monopodial or sympodial), stem size and aspect (naked or covered by marcescent leaves).

b) Leaf. Sheath type (open or closed) and shape, pubescence on sheaths (present or absent). Lamina type (sessile or pseudopetiolate), shape (linear, lanceolate, oblong, etc.), length, width, length-to-width ratio, type of adaxial pubescence (absent, sericeous, lanuginous, etc.). Pseudopetiole length. Angle and density of secondary nerves.

c) Inflorescence. Position (lateral or terminal), structure (simple or compound), organisation of main branches (monochasial or dichasial), axis length, number and distribution of bracts in the vegetative section.

d) Capitulum. Diameters of capitulum, ligular circle and disc, number or proportion of ray and disc flowers, length and colour of ray corollas, shape and texture of sterile phyllaries.

Key testing: the key was tested blindly, i.e. without knowing previously the identity of the individual, on living plants of the Espeletia species shown in Figure 1. Whenever possible, the key was tested on adult individuals that were in reproduction at the moment of the test or hold remnants of past reproduction events (dry inflorescences with attached capitula). However, tests of the key performance were also tried in juvenile/sterile individuals when fertile ones were exceedingly rare in the population assayed.

The key was also tested on herbarium samples of species E. angustifolia, E. arborea, E. aristeguietana, E. atropurpurea, E. badilloi, E. banksiifolia, E. batata, E. bracteosa, E. bromelioides, E. chardonii, E. cuatrecasasii, E. elongata, E. figueirasii, E. floccosa, E. griffinii, E. grisea, E. hanburyana, E. jabonensis, E. jahnii, E. leucactina, E. lindenii, E. lopezpalacii, E. lucida, E. marcescens, E. margarita, E. moritziana, E. nana, E. neriifolia, E. occulta, E. paltonioides, E. palustris, E. pannosa, E. ruizii, E. schultzii, E. semiglobulata, E. spectabilis, E. spicata, E. tamana, E. tenorae, E. thyrsiformis, E. timotensis, E. trujillensis, E. vergarae, E. viridis and E. weddellii. Specimens of these species were collected by the author and some colleagues and are now deposited at herbarium IVIC, in which the identification tests were performed blindly by IVIC staff that did not participate in the sampling.

\section{RESULTS}


Almost all living plants were correctly identified with this key. The few failures corresponded to some juvenile or sterile individuals with no remnants of past reproduction events, which did not allow the determination of diagnostic traits such as the position and structure of the inflorescence or the size of the capitula. This occasional difficulty did not prevent the correct identification of any species, since in all populations evaluated there were always individuals with inflorescences and capitula from on-going or past reproduction events. However, fertile individuals can be relative rare in certain monocarpic species, e.g. < $1 \%$ in E. jabonensis or E. paltonioides (Mavárez pers. obs), probably as a consequence of a high degree of reproductive synchronisation. The identification of individuals in this type of species was attempted using vegetative traits alone, with complete success.

The rate of correct identification for herbarium samples was also relatively high, about $90 \%$. The failures occurred in some herbarium sheets in which diagnostic information, such as the description of the pubescence of sheaths, the position of the inflorescence, or the length and colour of ray corollas, cannot be retrieved from the specimens or their labels.

\section{Literature Cited}

BerRy, P., BEAujon, S. AND R.N. CALvo. 1988. La hibridización en la evolución de los frailejones (Espeletia, Asteraceae). Ecotropicos. 1:11-24.

CuAtrecasas, J. 1996. Clave provisional de las especies del género Espeletiopsis Cuatrec. (Espeletiinae, Compositae). Anal. Jard. Bot. Mad. 54:370-377.

------. 2013. A Systematic Study of the Subtribe Espeletiinae (Heliantheae, Asteraceae). Mem. New York Bot. Gard. Vol. 107. The New York Botanical Garden Press, New York.

DiazGranados, M. 2012. A nomenclator for the frailejones (Espeletiinae Cuatrec., Asteraceae). PhytoKeys 16: 1-52. doi: 10.3897/phytokeys.16.3186.

DiAzGRANADOS, M. AND J. C. BARBER. 2017. Geography shapes the phylogeny of frailejones (Espeletiinae Cuatrec., Asteraceae): a remarkable example of recent rapid radiation in sky islands. PeerJ 5: e2968. doi:10.7717/peerj.2968.

Hooghiemstra, H., Wijninga, V. M. AND A. M. Cleef. 2006. The paleobotanical record of Colombia: Implications for biogeography and biodiversity. Ann. Missouri Bot. Gard. 93: 297-324.

Humboldt, A. AND A. BonPland. 1809[1808]. Plantae Aequinoctiales 2(9): 10. F. Schoell, Paris.

MAVÁREZ, J. 2019. A Taxonomic revision of Espeletia (Asteraceae). The Venezuelan Radiation. Harv. Pap. Bot. 24(2): 131-244.

Mavarez, J., AND M.T. BeCERRA. 2019. Taxonomic novelties in páramo plants. Espeletia ramosa (Asteraceae), a new species from Colombia. Phytologia 101(4): 222-230. 
Pouchon, C., Fernández, A., Nassar, J. M., Boyer, F., Aubert, S., Lavergne, S. And J. MAVÁREZ. 2018. Diversification of the Giant Rosettes of the Espeletia complex (Asteraceae). A Phylogenomic Analysis of an Explosive Adaptive Radiation in the Andes. Syst. Biol. 67: 1041-1060. Doi: 10.1101/gr.074492.107.

THIERS, B. 2019+ (continuously updated). Index Herbariorum: A global directory of public herbaria and associated staff. New York Botanical Garden's Virtual Herbarium, http://sweetgum.nybg.org/science/ih/ (accessed: May 1 2019).

Torres, V., H. Hooghiemstra AND L. Lourens. 2013. Astronomical tuning of long pollen records reveals the dynamic history of montane biomes and lake levels in the tropical high Andes during the Quaternary. Quat. Sci. Rev. 63: 59-72. doi: 10.1016/j. quascirev.2012.11.004.

\section{TAXONOMIC KEY}

1a. Trees

2a. Inflorescence structure primarily dichasial and in lateral position in regards with branch axis 3 (plate 1A)

3a. Pseudo-petiolate leaves. Vegetative part of the inflorescence leaf-less E. badilloi

3b. Sessile leaves. Vegetative part of the inflorescence with 1-2 pairs of opposite leaves E. trujillensis

2b. Inflorescence structure primarily monochasial and in terminal position in regards with branch axis

4a. Sessile leaves

5 (plate 1B)

5a. Secondary nerves $>4 \mathrm{~mm}$ apart

E. liscanoana

5b. Secondary nerves $<4 \mathrm{~mm}$ apart

6a. Leaf length $>15 \mathrm{~cm}$ E. occulta

6b. Leaf length $<15 \mathrm{~cm}$ E. parvula

4b. Pseudo-petiolate leaves 7 (plate 2)

7a. Sparsely branched, sympodial (pseudo-dichotomous). Sheaths open, semi-amplectant. Ray ligules bright yellow E. chardonii

7b. Profusely branched, monopodial. Sheaths either closed or open but entirely amplectant. Ray ligules absent or white, cream or pale-yellow 8

8a. Secondary nerves $>4 \mathrm{~mm}$ apart E. neriifolia

8b. Secondary nerves $<4 \mathrm{~mm}$ apart 9 
9a. Ray corollas eligulate

E. lucida

9b. Ray corollas ligulate 10

10a. Small shrubs and trees, usually $<4 \mathrm{~m}$ high. Leaf length $<15 \mathrm{~cm}$ E. griffinii

10b. Large trees $>4 \mathrm{~m}$ high. Leaf length $>15 \mathrm{~cm}$. 11

11a. Sheaths adaxially barbate 12

12a. Oblong leaves (ratio 2-5:1) with dentate margins

E. banksiifolia

12b. Lanceolate leaves (ratio 6-9:1) with entire margins

E. tamana

11b. Sheaths adaxially glabrous 13

13a. Capitulum diameter $>12 \mathrm{~mm}$ E. arborea

13b. Capitulum diameter $<12 \mathrm{~mm}$ E. divisoriensis

1b. Rosettes 14

14a. Terminal inflorescences (monocarpic rosettes) 15

15a. Leaves adaxially glabrous 16

16a. Sessile rosettes or with short-branched stems 17 (plate 3A)

17a. Leaves with oblong outline, pseudo-petiolate or strongly attenuated near the base 18

18a. Ray corollas eligulate E. atropurpurea

18b. Ray corollas white E. usubillagae

18c. Ray corollas yellow E. bracteosa

17b. Leaves with linear or cuneiform outline 19

19a. Ray corollas yellow E. viridis

19b. Ray corollas eligulate 20

20a. Leaves with flat margins and basal nerves parallel to axis E. bromelioides

20b. Leaves with revolute margins and obsolete secondary nerves E. jahnii

16b. Caulescent rosettes with unbranched stems 21 (plate 3B)

21a. Leaves broadly oblong (ratio $<6.5: 1$ ) 22 
22a. Tubular sheaths. Leaves with unfolded margin and obtuse apex, secondary nerves 1-3 $\mathrm{mm}$ apart, deviation angles $70-90^{\circ}$ E. spectabilis

22b. Open sheaths. Leaves with folded margin and acute apex 23

23a. Leaf usually with small basal folding, secondary nerves $2-5 \mathrm{~mm}$ apart, deviation angles $70-90^{\circ}$, capitulum diameter $>20 \mathrm{~mm}$. Ray ligules pale-yellow or greenish ....... E. marcescens

23b. Leaf usually with large basal folding, secondary nerves $4-8 \mathrm{~mm}$ apart, deviation angles $60-65^{\circ}$, capitulum diameter $<18 \mathrm{~mm}$. Ray corollas pinkish-reddish E. cuatrecasasii

21b. Leaves with linear or linear-lanceolate outline (ratio $>14: 1$ ) 24

24a. Ray corollas eligulate E. figueirasii

24b. Ray corollas ligulate 25

25a. Leaves pseudo-petiolate E. cardonae

25b. Leaves with sessile outline 26

26a. Leaves linear (ratio 20-45:1). Ray corollas white when young, turning pink-reddish when old. Tips of external phyllaries surpass the ligular circle E. ruizii

26b. Leaves linear-lanceolate (ratio 14-23:1). Ray corollas white. Tips of external phyllaries do not surpass the ligular circle E. hanburyana

15b. Leaves adaxially pubescent

27a. Sessile rosettes or with short stems 28 (plate 4A)

28a. Ray corollas white, cream or pale-yellow 29

29a. Leaves with oblong-oblanceolate outline (ratio 7-9:1). Outer phyllaries broad, green, foliaceous and reticulate E. lindenii

29b. Leaves with linear-lanceolate outline (ratio $>15: 1$ ). Outer phyllaries linear-triangular, pubescent. Ray corollas white

30a. Leaves with linear outline (ratio 20-40:1), secondary nerves obsolete or scarce, deviation angles $20-30^{\circ}$. Length of ray corollas $>13 \mathrm{~mm}$ E. margarita

30b. Leaves with linear-lanceolate outline (ratio 15-30:1), secondary nerves 1-3 mm apart, deviation angles $60-80^{\circ}$. Length of ray corollas $<10 \mathrm{~mm}$ E. leucactina

28b. Ray corollas yellow

31a. Sheaths rectangular and slightly broader than lamina. Leaves with linear outline (ratio 30-40:1), secondary nerves obsolete, silvery-sericeous indumentum E. jabonensis 
31b. Sheaths oblong and clearly broader than lamina. Leaves with linear-lanceolate outline (ratio $<20: 1)$

32a. Leaves with silvery-sericeous indumentum, secondary nerves obsolete or thin, 2-4 mm apart, deviation angles $25-50^{\circ}$. Ligular circles $>40 \mathrm{~mm}$ E. floccosa

32b. Leaves with appressed-sericeous indumentum, secondary nerves 10-15 mm apart, deviation angles $15-30^{\circ}$. Ligular circles $<35 \mathrm{~mm}$ E. vergarae

27b. Caulescent rosettes with unbranched stems 33 (plate 4B)

33a. Length of ray corollas $>8 \mathrm{~mm}$ 34

34a. Leaves pseudo-petiolate, secondary nerves $5-8 \mathrm{~mm}$ apart, deviation angles $45-75^{\circ}$. Ray corollas yellow

E. emmanuelis

34b. Leaves sessile, secondary nerves $2-4 \mathrm{~mm}$ apart, deviation angles $70-85^{\circ}$. Ray corollas white or pale-yellow, outer phyllaries broad, green, foliaceous and reticulate E. lindenii

33b. Length of ray corollas $<8 \mathrm{~mm}$ 35

35a. Secondary nerves $1-3 \mathrm{~mm}$ apart, deviation angles $50-70^{\circ}$. Capitulum diameter $>12 \mathrm{~mm}$, ligular circle $>15 \mathrm{~mm}$ E. grisea

35b. Secondary nerves $>4 \mathrm{~mm}$ apart, deviation angles $<40^{\circ}$. Capitulum diameter $<12 \mathrm{~mm}$, ligular circle $<15 \mathrm{~mm}$ 36

36a. Stems covered with old leaves/sheaths, up to $1 \mathrm{~m}$ high. Capitulum radiate, ray corollas 4.5-6.5 mm long, ligules white E. lopezpalacii

36b. Stems mostly leaf-less, up to $10 \mathrm{~m}$ high. Capitulum short-radiate, ray corollas 2.0-3.5 $\mathrm{mm}$ long, ligules pale-yellow E. paltonioides

14b. Lateral inflorescences (polycarpic rosettes) 37

37a. Inflorescences mono- or oligocephalous $(<5$ capitula) 38 (plate 5)

38a. Large rosettes (leaf length $>25 \mathrm{~cm}$ )

39a. Sheath length $5.0-7.0 \mathrm{~cm}$, sheath width $0.9-2.2 \mathrm{~cm}$. Leaves with yellowish-greenish indumentum. Inflorescences bracteate. Capitulum with 600-860 disc flowers and 400-740 ray flowers E. moritziana

39b. Sheath length $7.0-10.0 \mathrm{~cm}$, sheath width $2.2-2.5 \mathrm{~cm}$. Leaves with white indumentum. Inflorescences aphyllous. Capitulum with 215-280 disc flowers and 95-200 ray flowers E. palustris

38 b. Small rosettes (leaf length $<15(25) \mathrm{cm}$ ) 40

40a. Sheaths abaxially glabrous 41 
41a. Leaves usually cub-shaped, with lanuginous indumentum. Inflorescences frequently aphyllous, sometimes with 1-2 alternate or opposite bracts in the upper half. Capitulum densely pubescent, diameter $40-50 \mathrm{~mm}$, ligular circle smaller than the involucre $(20-30 \mathrm{~mm})$, disc diameter $16-18 \mathrm{~mm}$. Capitulum with $53-57 \%$ ray flowers

E. tenorae

41b. Leaves lanceolate, with silvery-sericeous indumentum. Inflorescences with 3-5 pairs of opposite bracts. Capitulum diameter 19-21 mm, ligular diameter 30-35 mm, disc diameter $16-18 \mathrm{~mm}$. Capitulum with $35-45 \%$ ray flowers E. marthae

41c. Leaves oblong-lanceolate, with lanuginous indumentum. Inflorescences with 2 pairs of opposite bracts. Capitulum diameter 20-26 mm, ligular diameter $24-35 \mathrm{~mm}$, disc diameter $12-16 \mathrm{~mm}$. Capitulum with $45-52 \%$ ray flowers E. nana

40b. Sheaths abaxially barbate. 42

42a. Leaves oblong-lanceolate, with lanuginous indumentum. Inflorescences with 2-3 pairs of opposite bracts. Capitulum diameter 18-24 mm, ligular diameter 30-40 mm, disc diameter $12-15 \mathrm{~mm}$. Capitulum with $50-52 \%$ ray flowers E. batata

42b. Leaves with revolute margins and cylindrical outline, with crispy-lanuginous indumentum. Inflorescences frequently monocephalous, rarely with 2-3 capitula, also with 12 pairs of opposite bracts. Capitulum diameter 24-32 mm, ligular diameter 40-45 mm, disc diameter $20-25 \mathrm{~mm}$. Capitulum with $30-35 \%$ ray flowers E. ulotricha

42c. Leaves lanceolate, with sub-appressed villous indumentum. Inflorescences frequently with 2-5 capitula, rarely 1 , also with 2 pairs of opposite bracts (rarely 1 or 3 ). Capitulum diameter 15-25 mm, ligular diameter 20-30 mm, disc diameter 10-15 mm. Capitulum with $37-47 \%$ ray flowers E. weddellii

37b. Inflorescences polycephalous ( $>5$ capitula)

43a. Capitula erect, ligular circles much larger than the involucres 44 (plate 6)

44a. Inflorescences monochasial, corymboid-paniculate. Ray corollas white 45

45a. Leaves with linear outline (ratio 30-40:1) and silvery-sericeous indumentum E. pannosa

45b. Leaves with linear-lanceolate outline (ratio 20-25:1) and lanuginous indumentum E. angustifolia

44b. Inflorescences dichasial, thyrsoid. Ray corollas yellow 46

46a. Leaves with oblong outline (ratio 4.0-5.7:1) and green tomentose-velvety indumentum. Capitulum diameter 10-14 mm, ligular diameter 24-28 mm, disc diameter 10-11 mm E. aristeguietana 
46b. Leaves with oblong outline (ratio 4.7-12.0:1) and whitish-greyish lanuginose indumentum. Capitulum diameter 20-30 mm, ligular diameter $30-50 \mathrm{~mm}$, disc diameter 12 $18 \mathrm{~mm}$ E. schultzii

43b. Capitula dropping or nodding. Ligular circles usually smaller than the involucres, occasionally equal or slightly larger 47 (plate 7)

47a. Inflorescences simple, monochasial (strict botryoid)

48a. Leaves with linear-lanceolate outline (ratio 20-35:1). Inflorescences with 14-38 monocephalous peduncles. Capitulum diameter 15-25 $\mathrm{mm}$ E. spicata

48b. Leaves with lanceolate outline (ratio 10-18:1). Inflorescences with 8-15 monocephalous peduncles. Capitulum diameter $35-55 \mathrm{~mm}$ E. timotensis

48c. Leaves with lanceolate outline (ratio 9-10:1). Inflorescences with 9-11 monocephalous peduncles. Capitulum diameter $35-55 \mathrm{~mm}$ E. albarregensis

47b. Inflorescences compound (at least basal peduncles polycephalous), monochasial or dichasial 49

49a. Leaves with oblong outline (ratio 4-10:1), sessile, with secondary nerves 5-10 mm apart. Inflorescences monochasial, with 17-35 peduncles, basal ones usually polycephalous (rarely monocephalous) E. thyrsiformis

49b. Leaves with lanceolate outline (ratio 9-20:1), distinctly pseudo-petiolate 50

50a. Secondary nerves 5-7 $\mathrm{mm}$ apart. Inflorescences monochasial, with 30-60 peduncles, basal one polycephalous E. elongata

50b. Secondary nerves $2-4 \mathrm{~mm}$ apart. Inflorescences dichasial, thyrsoid E. semiglobulata 


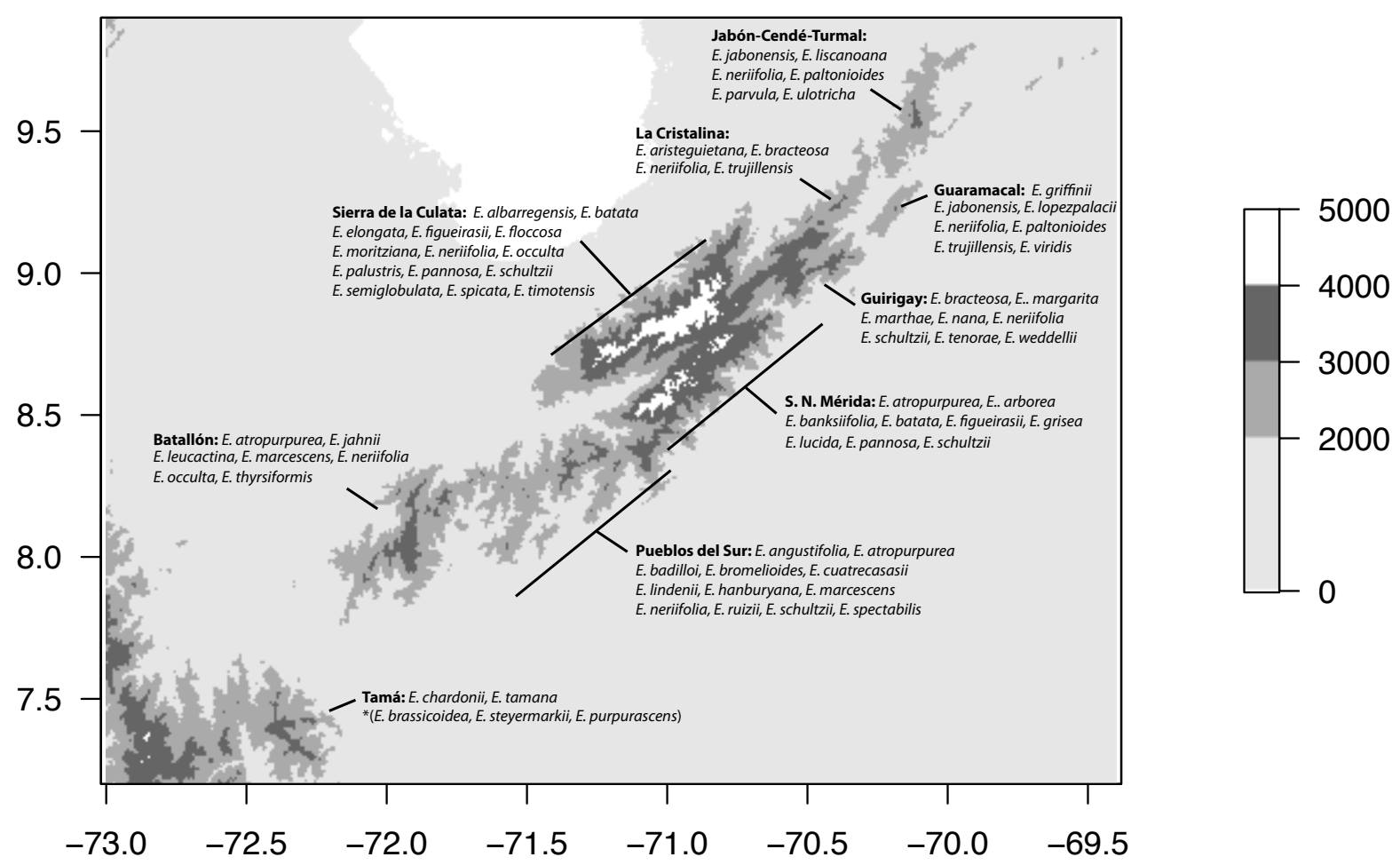

Figure 1. Espeletia species used for tests of key performance in living plants and their geographic locations (páramo names given in boldface). The three species marked with (*) are found in Páramo de Tamá but do not belong to the Venezuelan Espeletia clade.

Plates legends: Schematic representations of leaf outlines and inflorescences of species in the Venezuelan Espeletia clade. Leaf sheaths not shown unless otherwise stated. Abbreviations: r: leaf length to width ratio, $\varnothing$ : capitulum diameter, LC: ligular circle diameter, disc: disc diameter, \%RF: proportion of ray flowers. 
1A. Trees with dichasial inflorescences
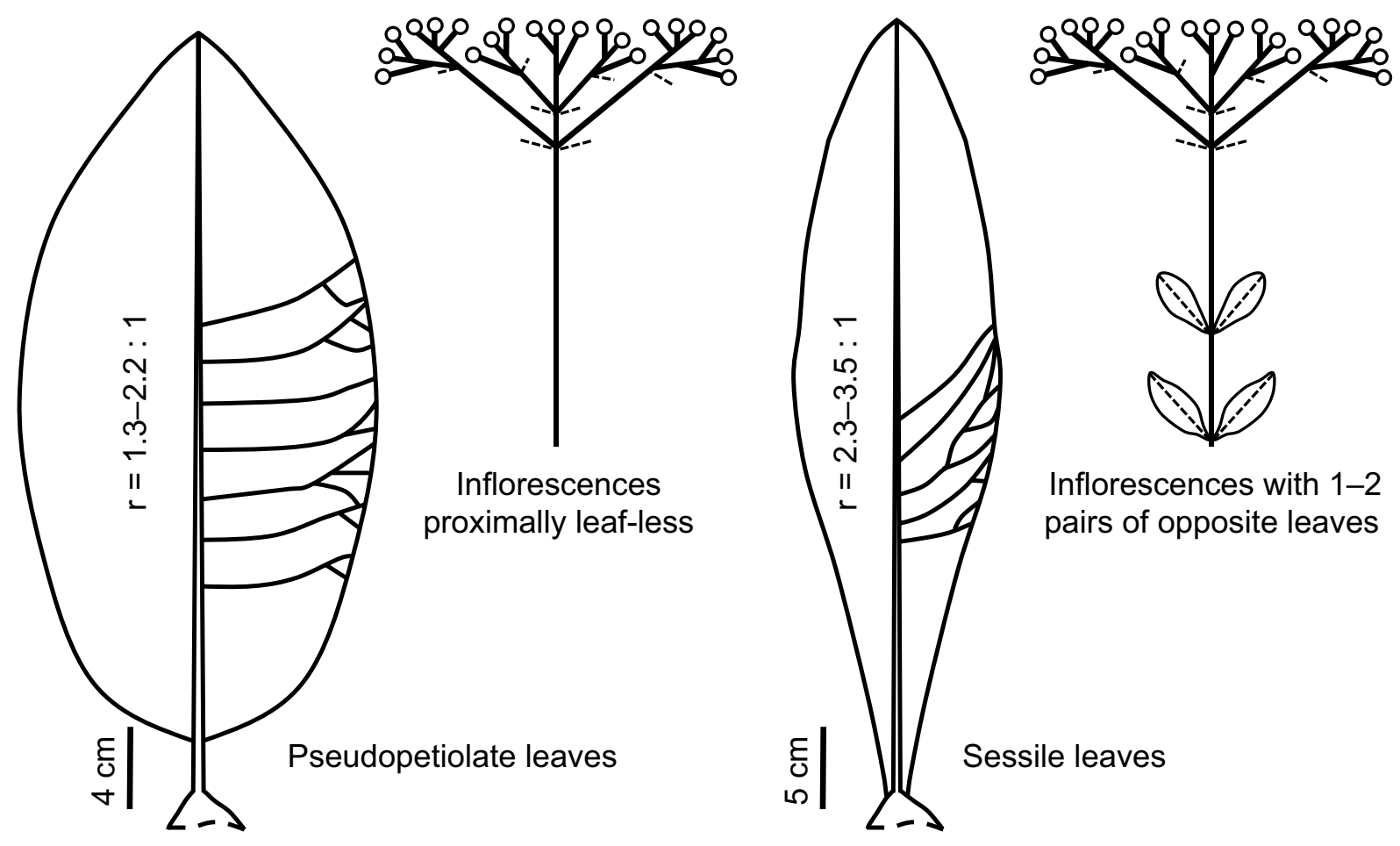

E. badilloi

E. trujillensis

1B. Trees with monochasial inflorescences, sessile leaves
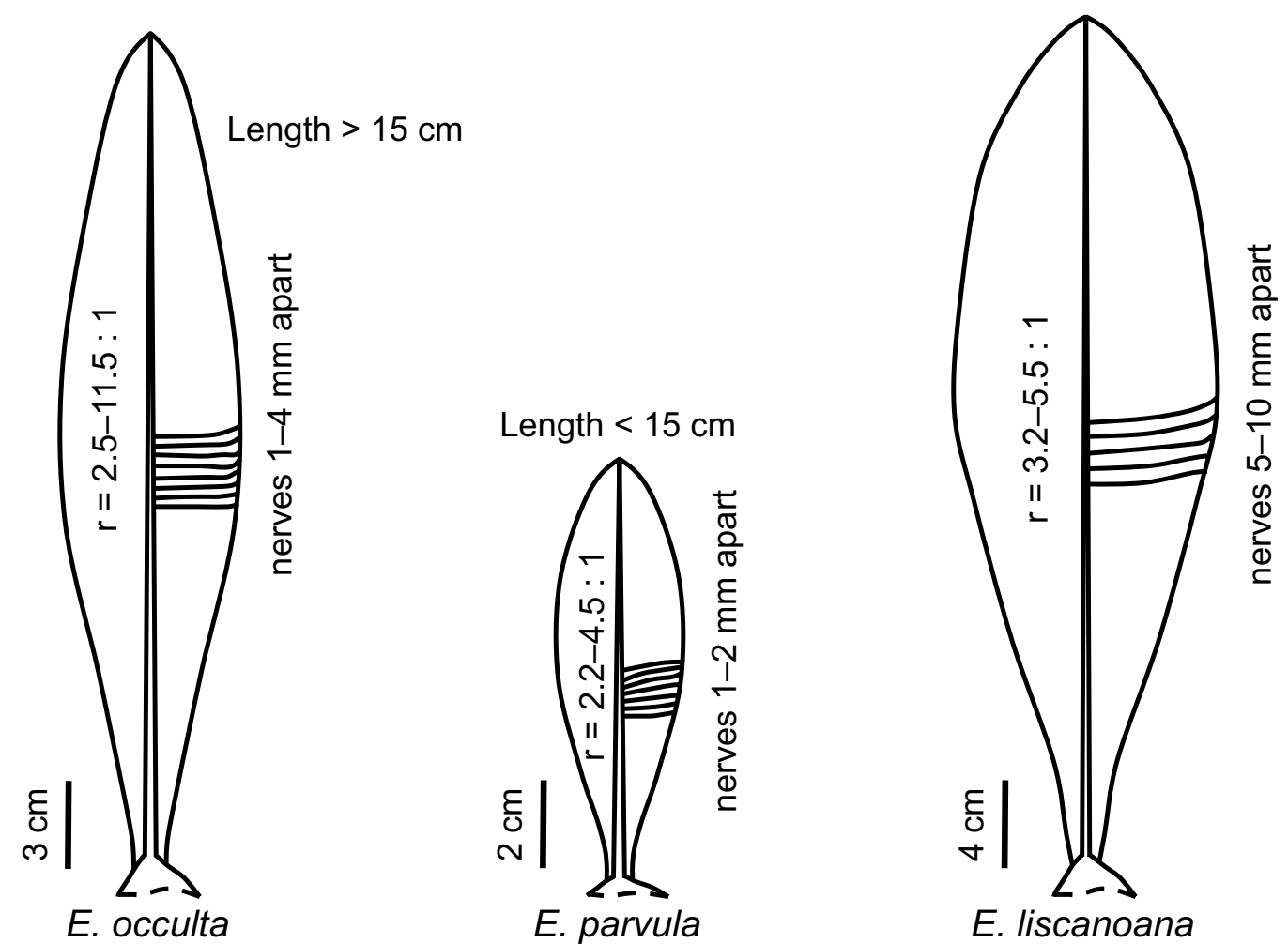
2. Trees with monochasial inflorescences, pseudopetiolate leaves

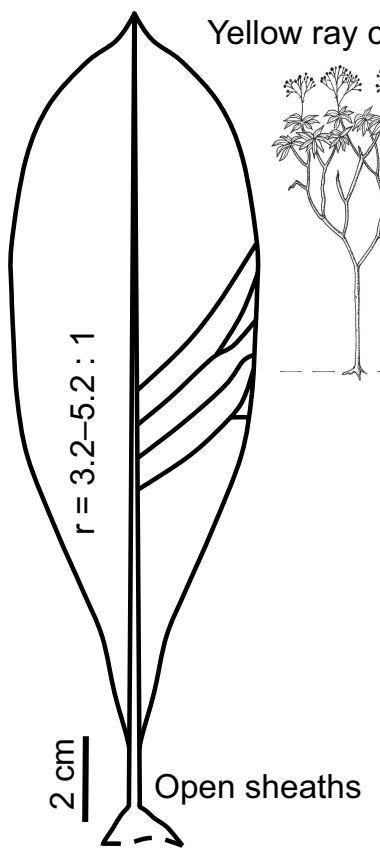

E. chardonii

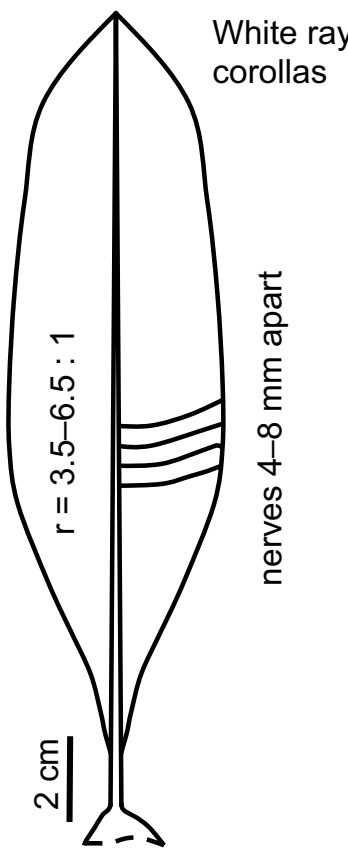

E. neriifolia

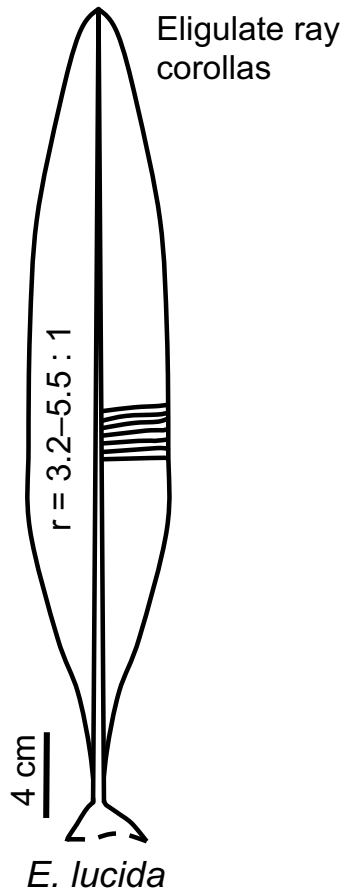

E. lucida

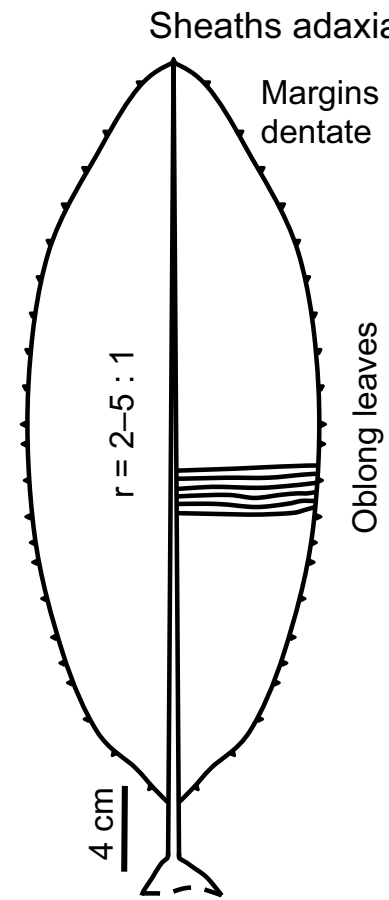

E. banksiifolia

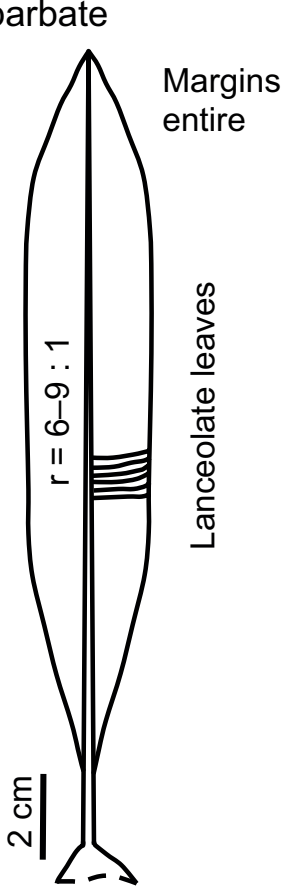

E. tamana

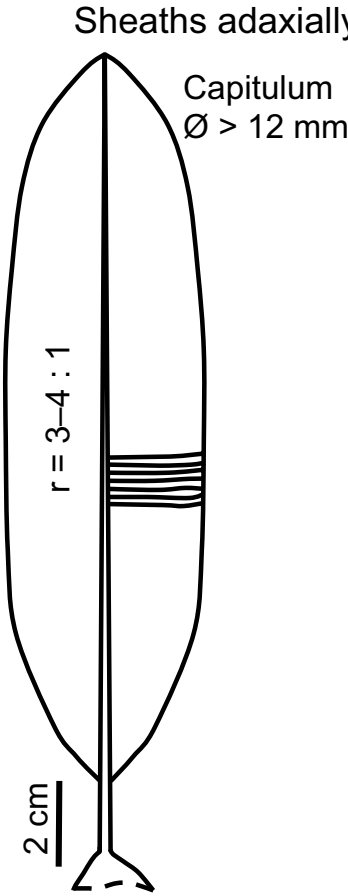

E. arborea

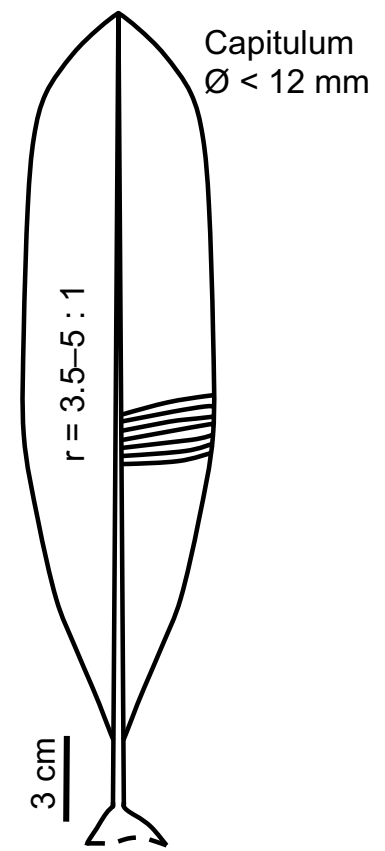

E. divisoriensis 
3A. Monocarpic rosettes, sessile or short-branched, adaxially glabous leaves

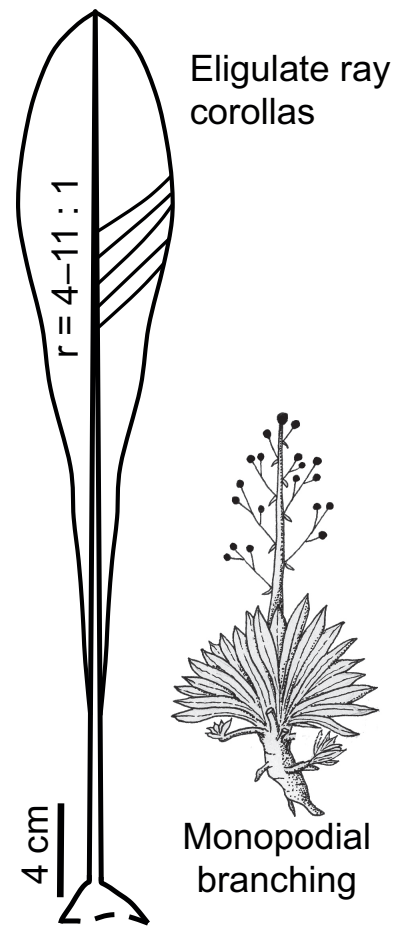

E. atropurpurea

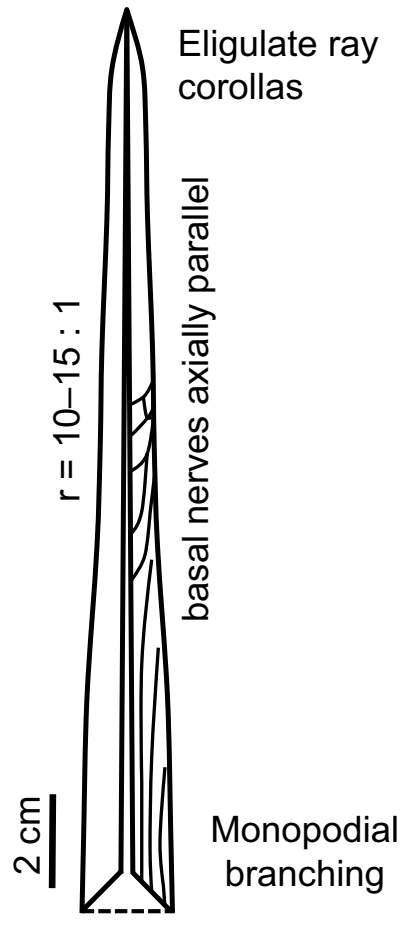

E. bromelioides

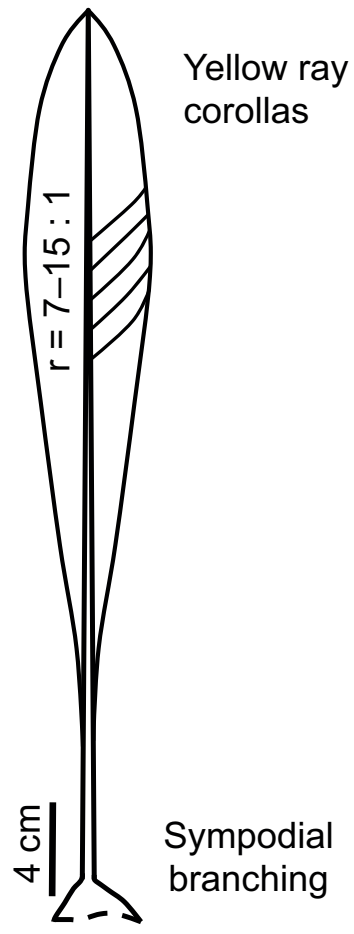

E. bracteosa

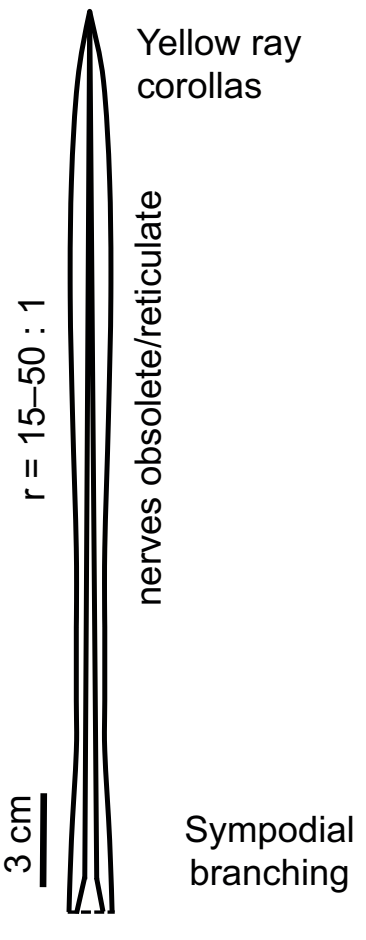

E. viridis

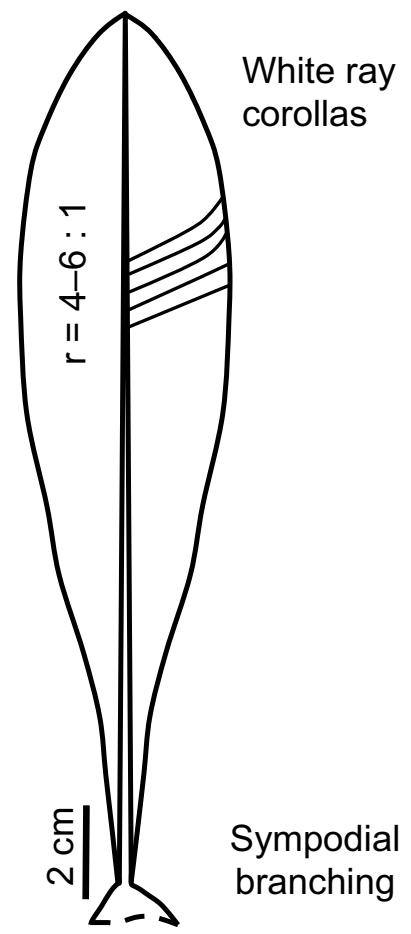

E. usubillagae

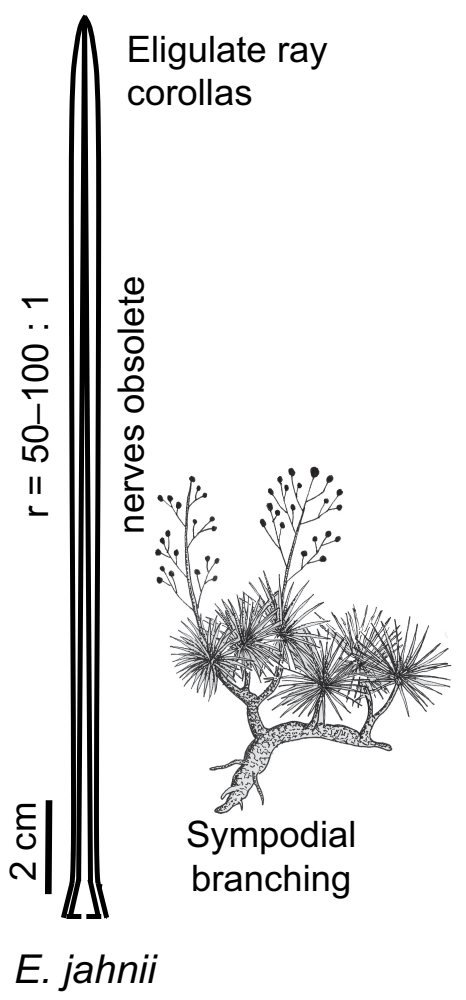


3B. Monocarpic unbranched caulescent rosettes, adaxially glabrous leaves

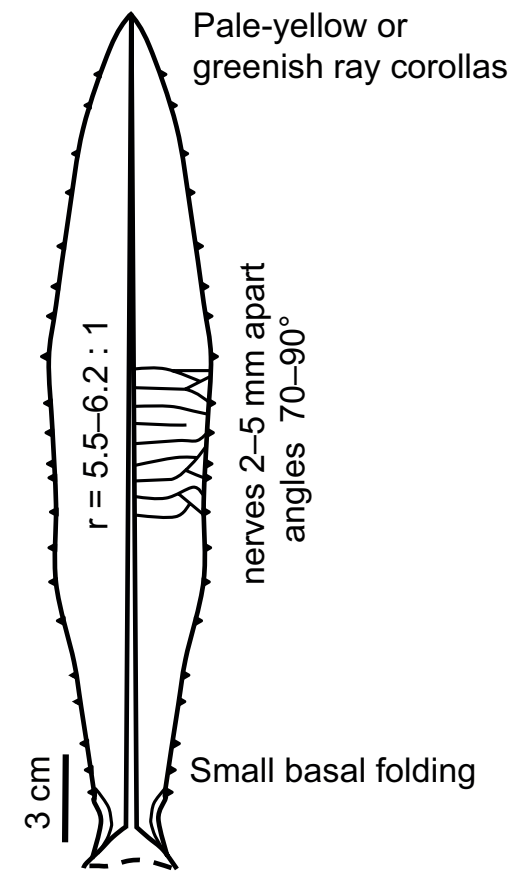

E. marcescens

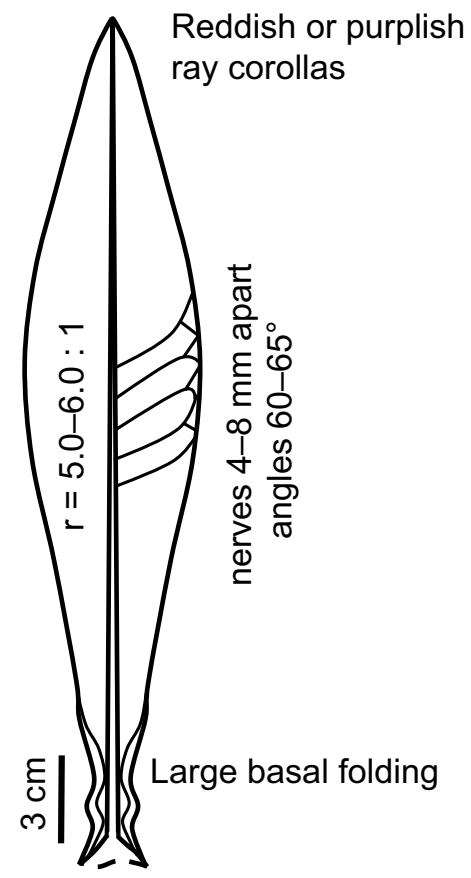

E. cuatrecasasii

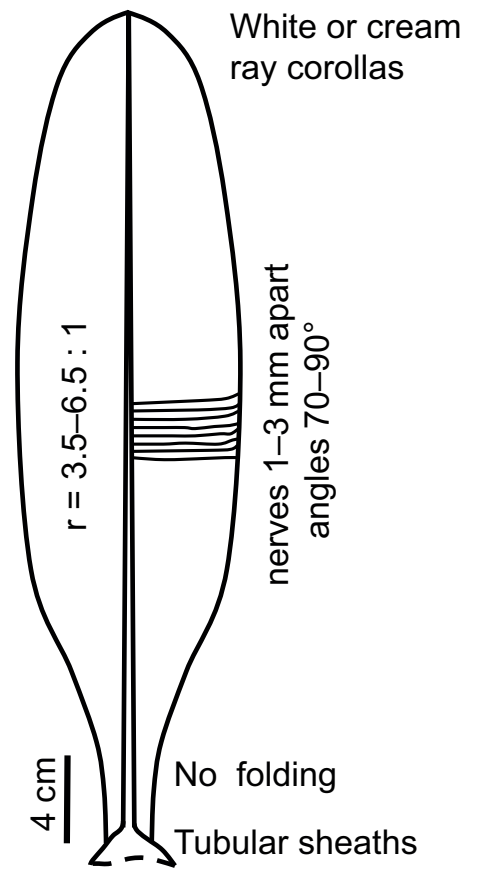

E. spectabilis

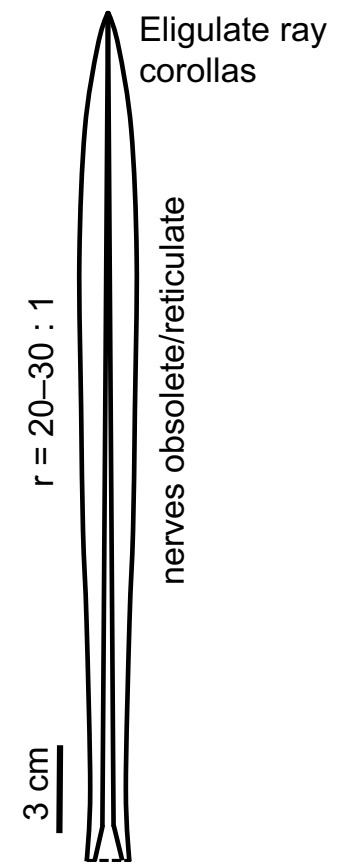

E. figueirasii

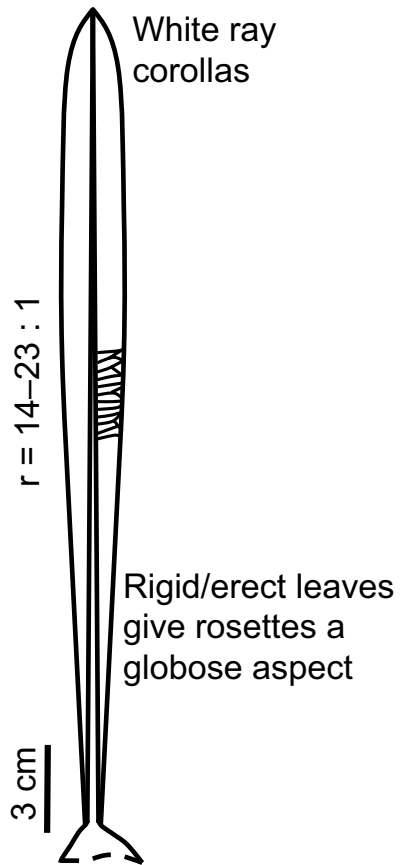

E. hanburyana

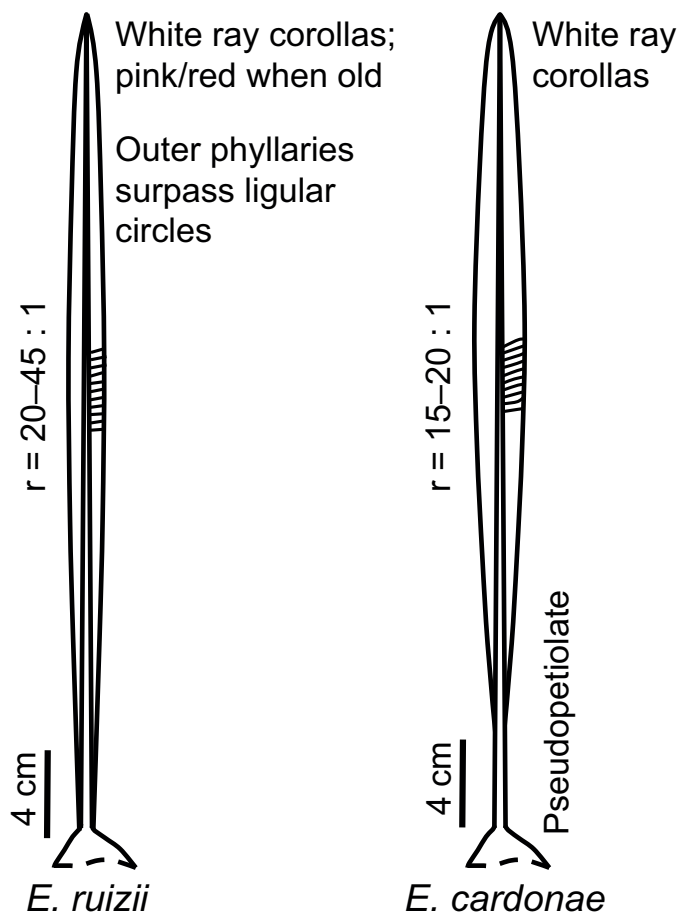


4A. Monocarpic rosettes, sessile or short-branched, adaxially pubescent leaves

White, cream or pale-yellow ray ligules
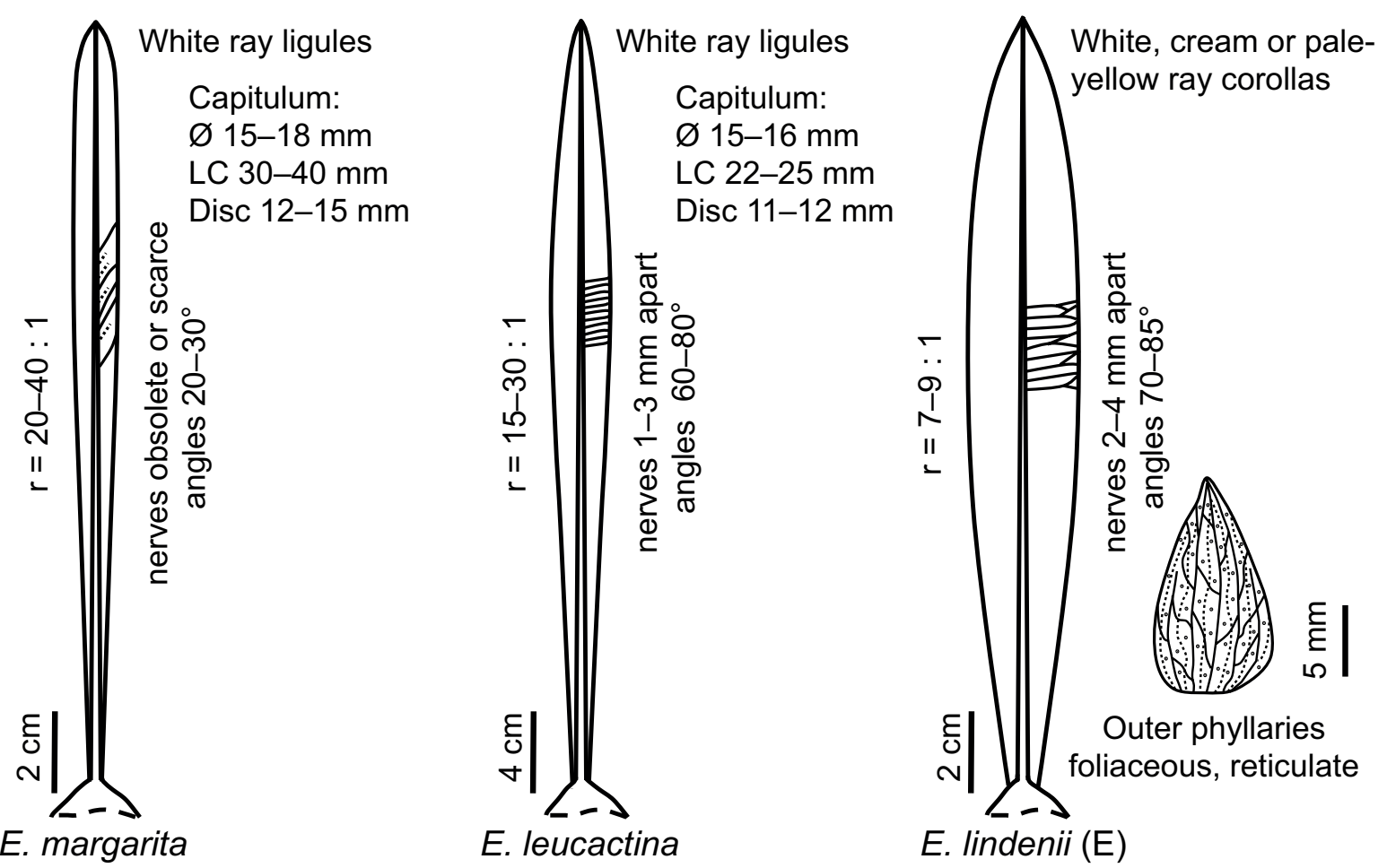

E. leucactina

E. lindenii $(\mathrm{E})$

Yellow ray ligules
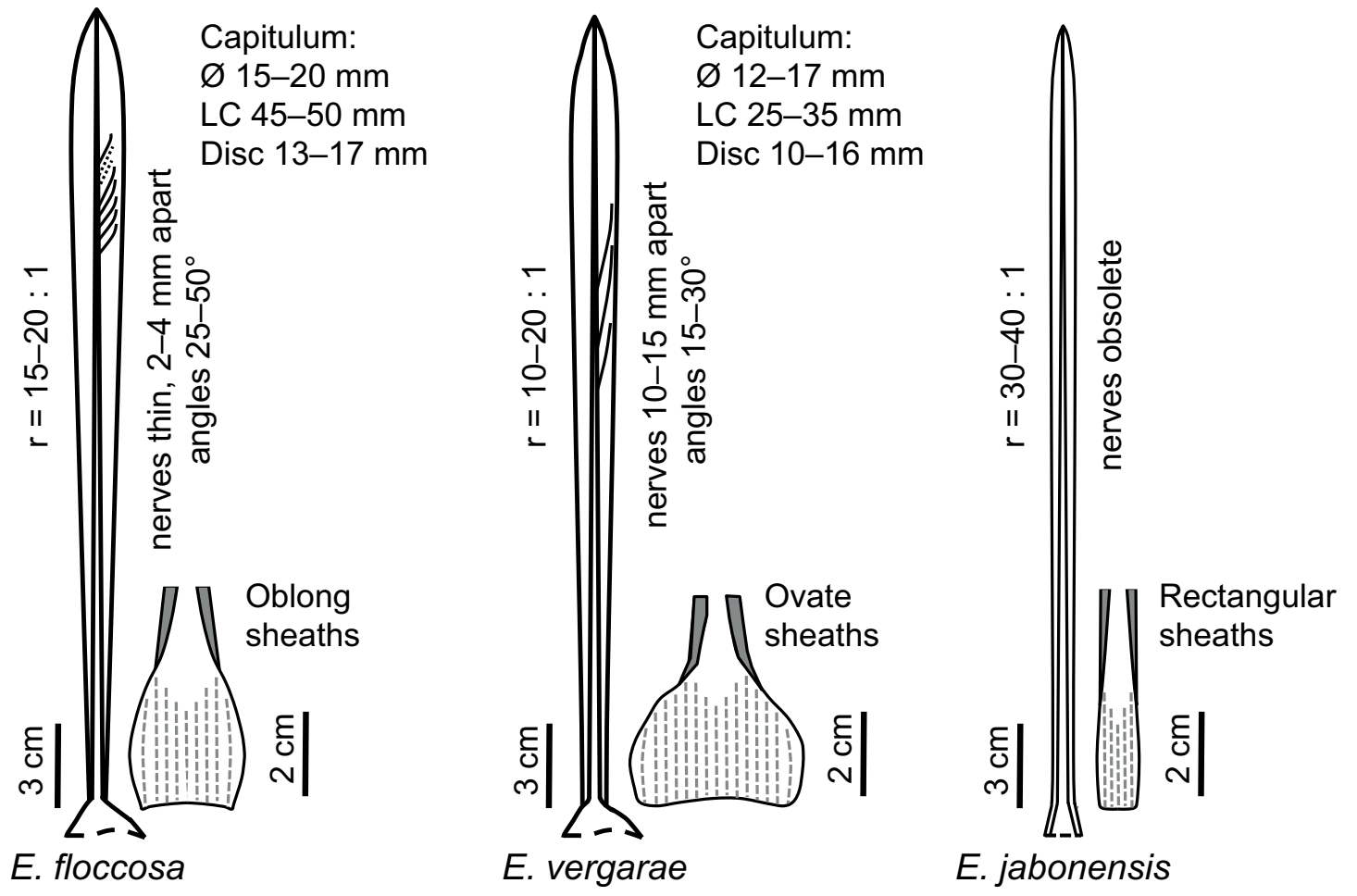
Ray corollas $>8 \mathrm{~mm}$

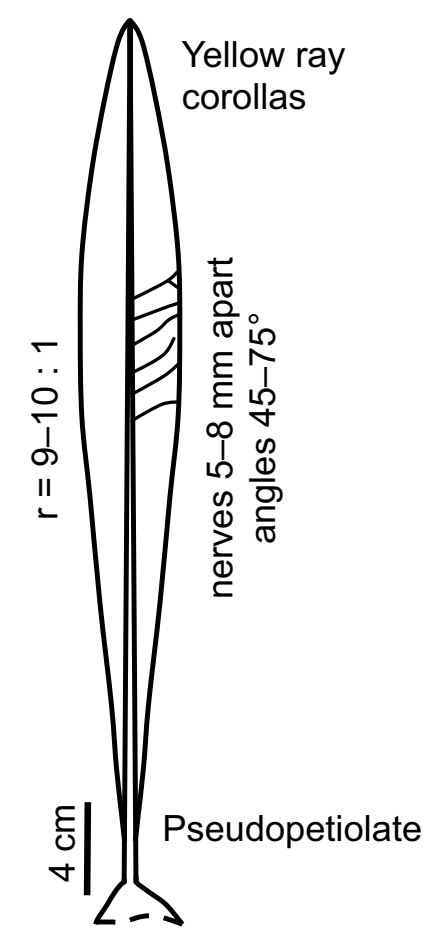

E. emmanuelis

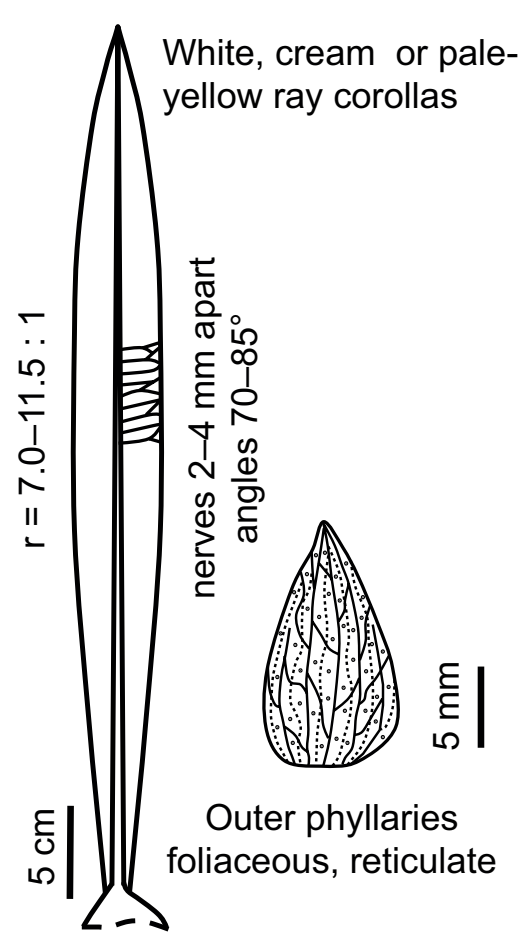

E. lindenii (W)

Ray corollas $<7 \mathrm{~mm}$

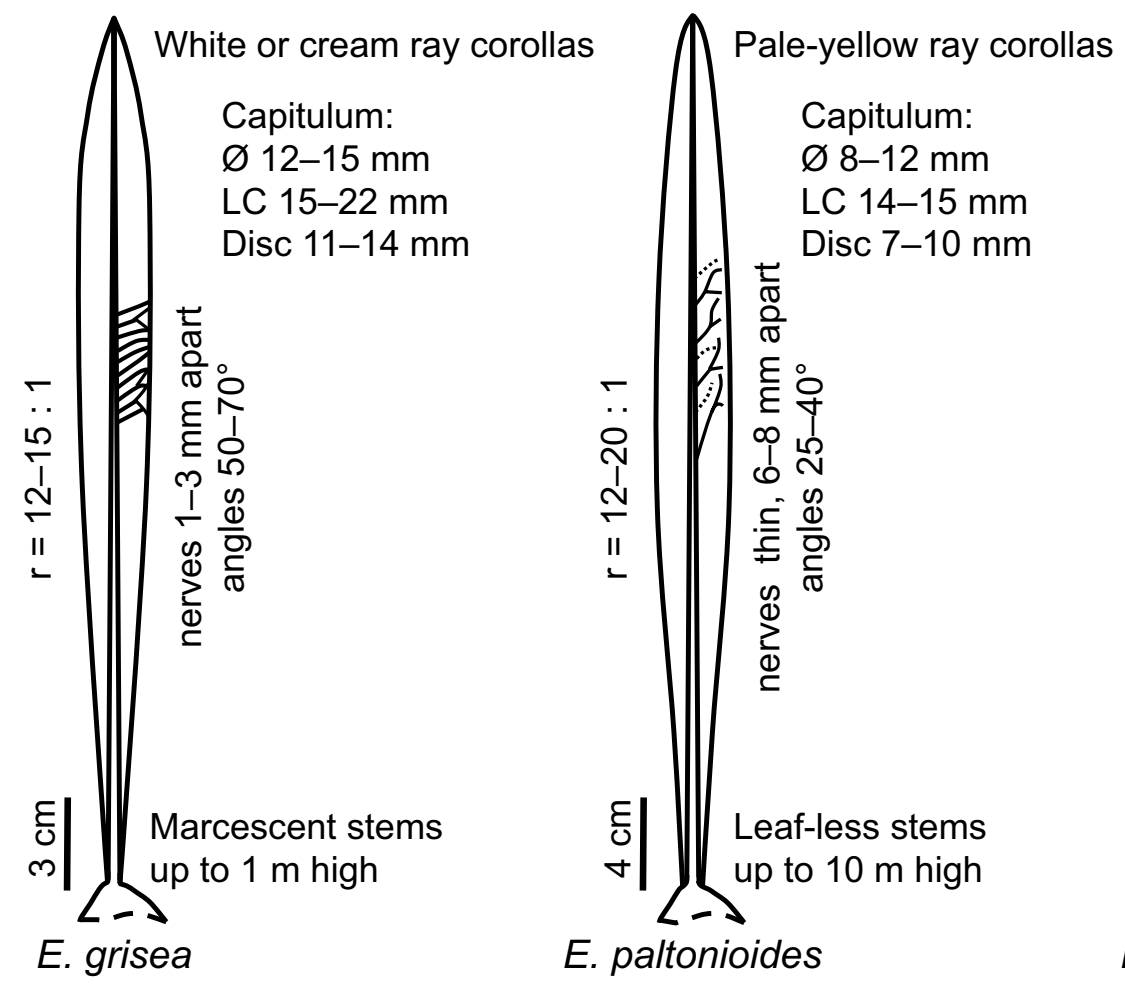

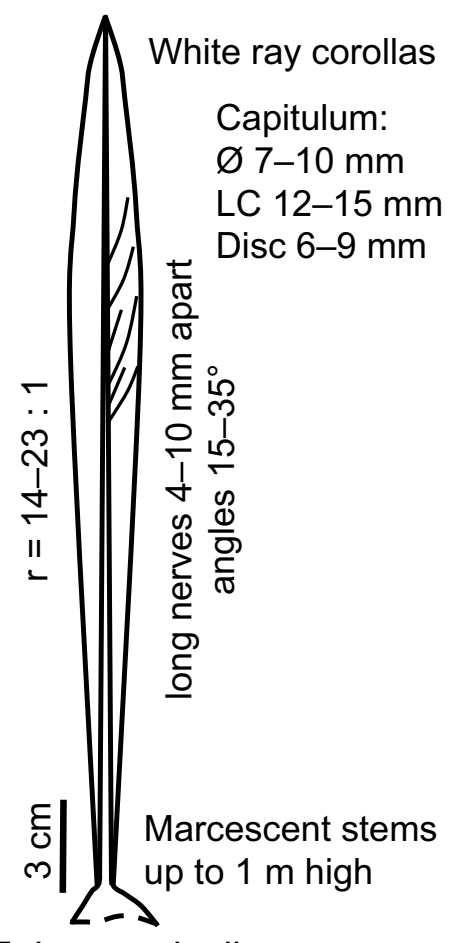

E. lopezpalacii 


\section{Polycarpic rosettes, mono- or oligocephalous inflorescences}

\section{Sheaths abaxially glabrous}

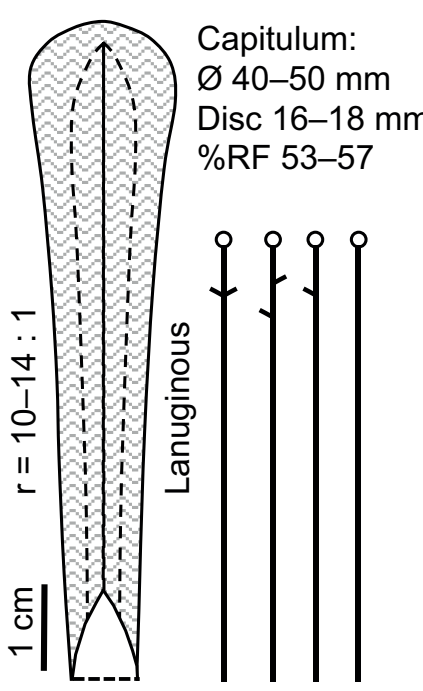

E. tenorae

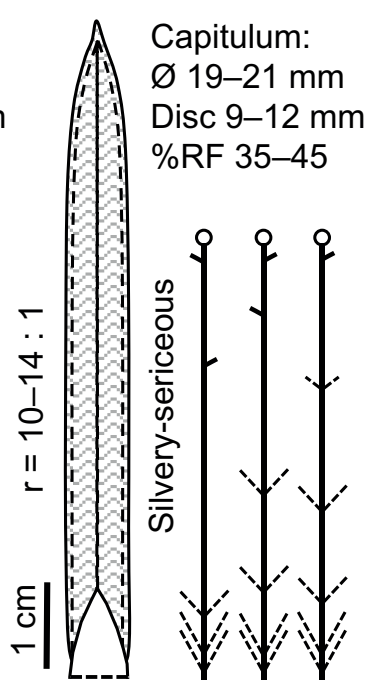

E. marthae

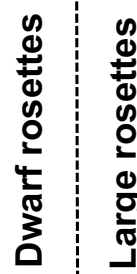

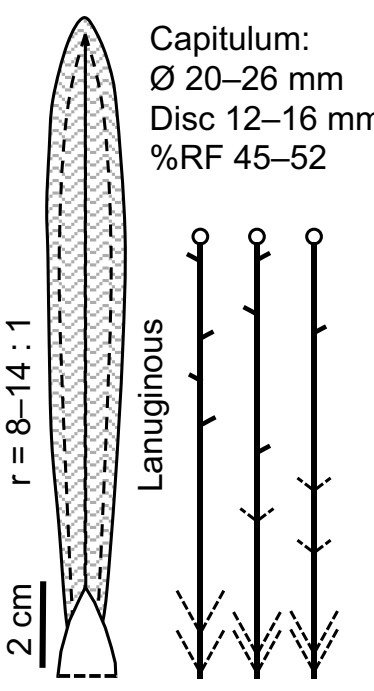

E. nana

\section{Sheaths abaxially barbate}

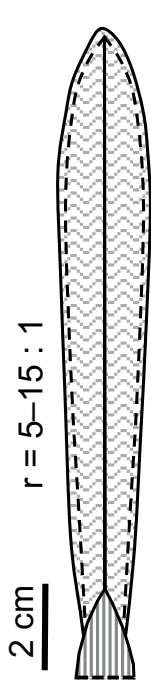

E. batata
Capitulum:

$\varnothing 18-24 \mathrm{~mm}$

Disc $12-15 \mathrm{~mm}$

$\%$ RF $50-52$

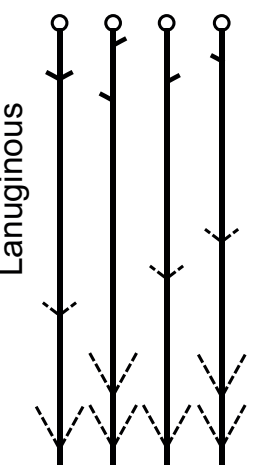

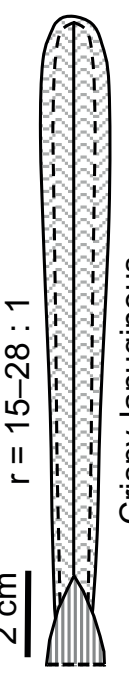

E. ulotricha
Capitulum: $\varnothing 24-32 \mathrm{~mm}$ Disc 20-25 mm \%RF 30-35

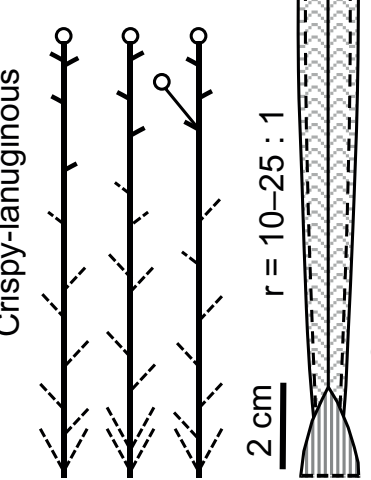

E. weddellii
Capitulum: Ø 15-25 mm Disc 10-15 mm \%RF 37-47

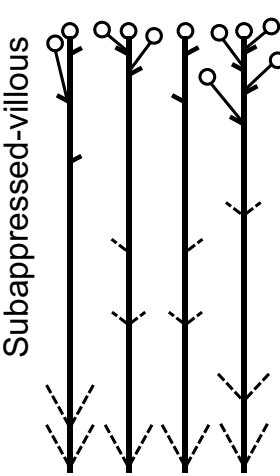

\begin{tabular}{l|l} 
딩 \\
$\forall$
\end{tabular}

E. palustris 
6. Polycarpic rosettes, polycephalous, ligular circles larger than involucres

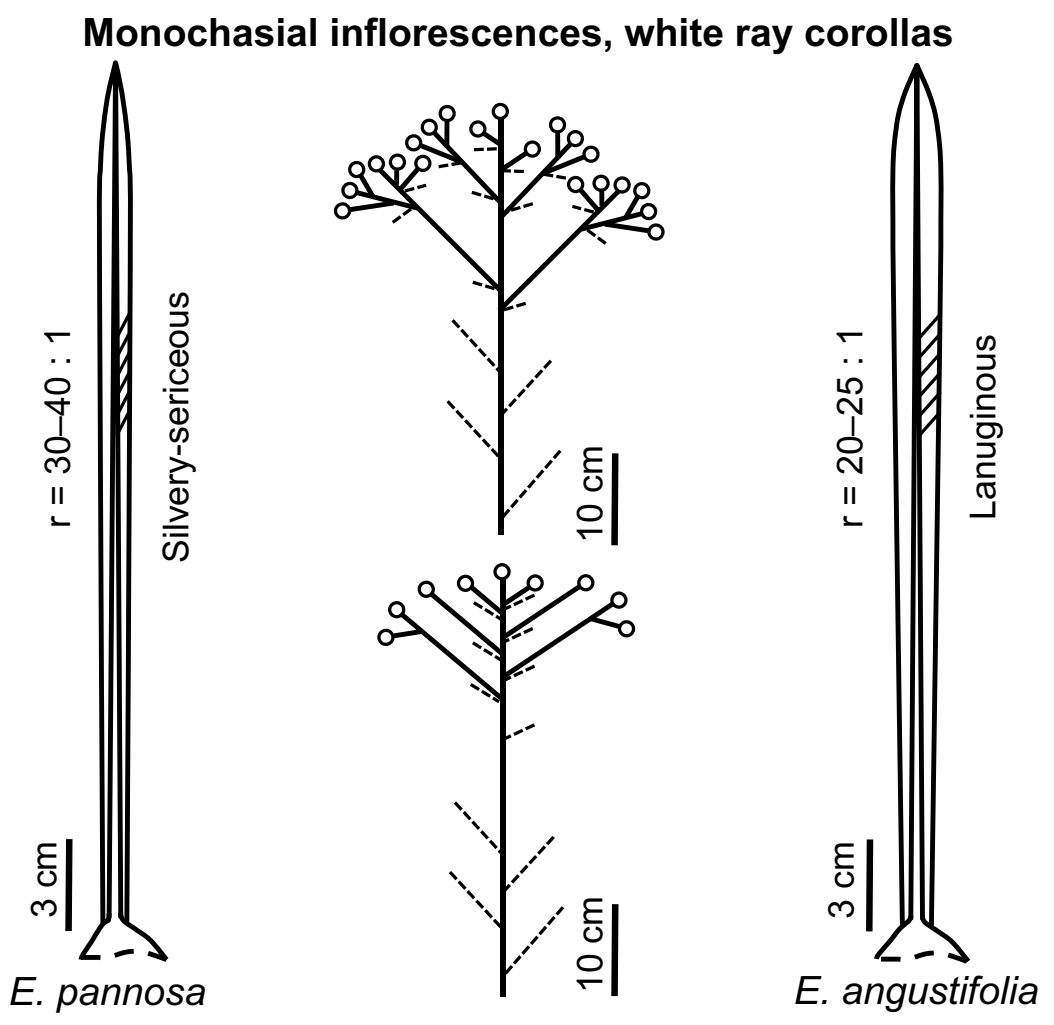

Dichasial inflorescences, yellow ray corollas
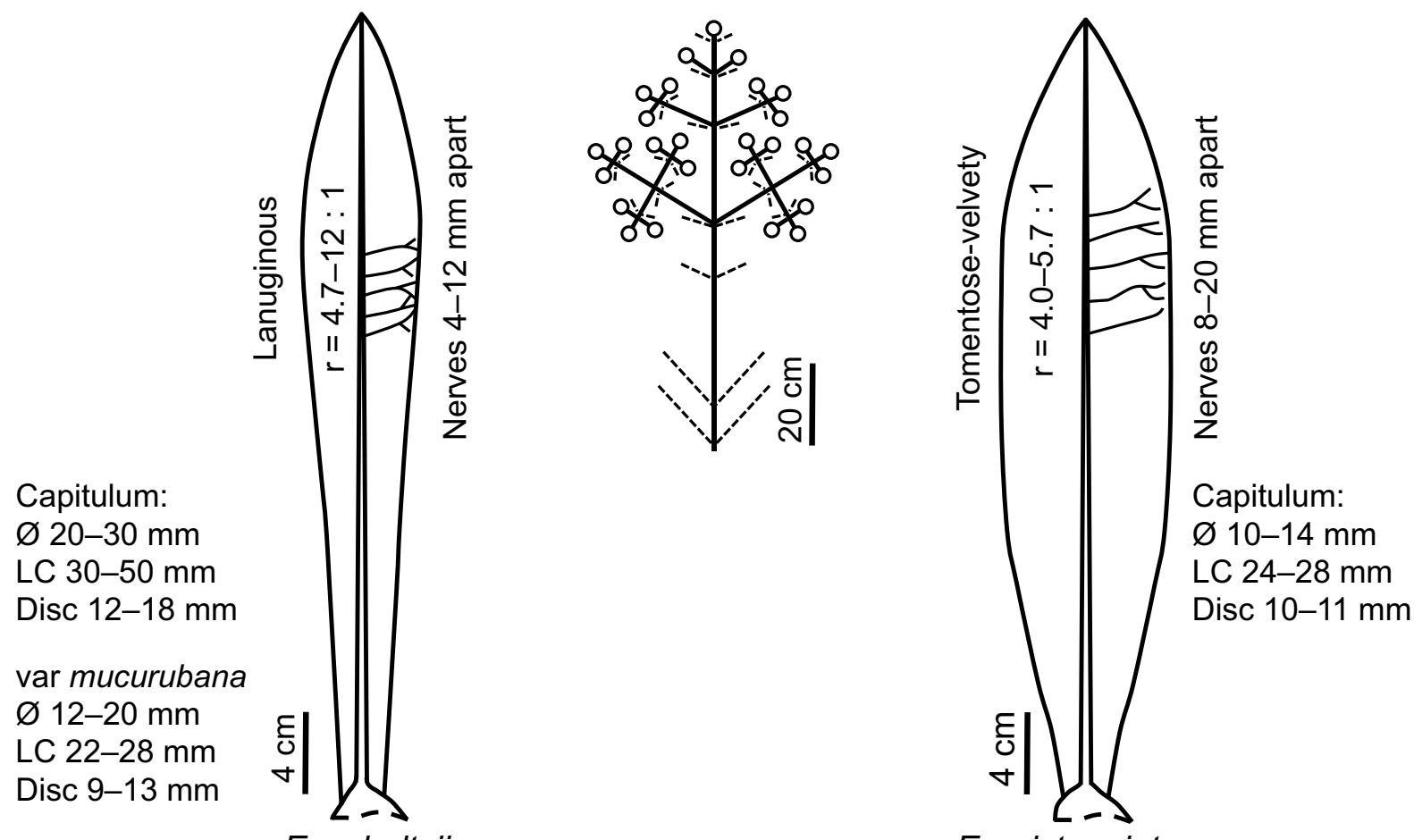

E. schultzii

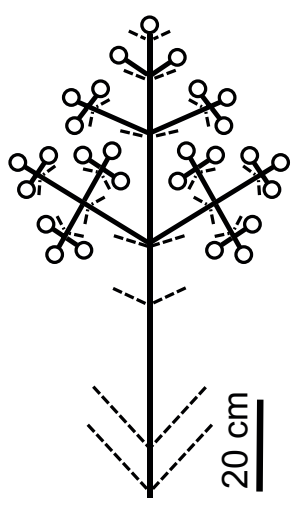

E. aristeguietana 
7. Polycarpic rosettes, polycephalous, ligular circles smaller than involucres

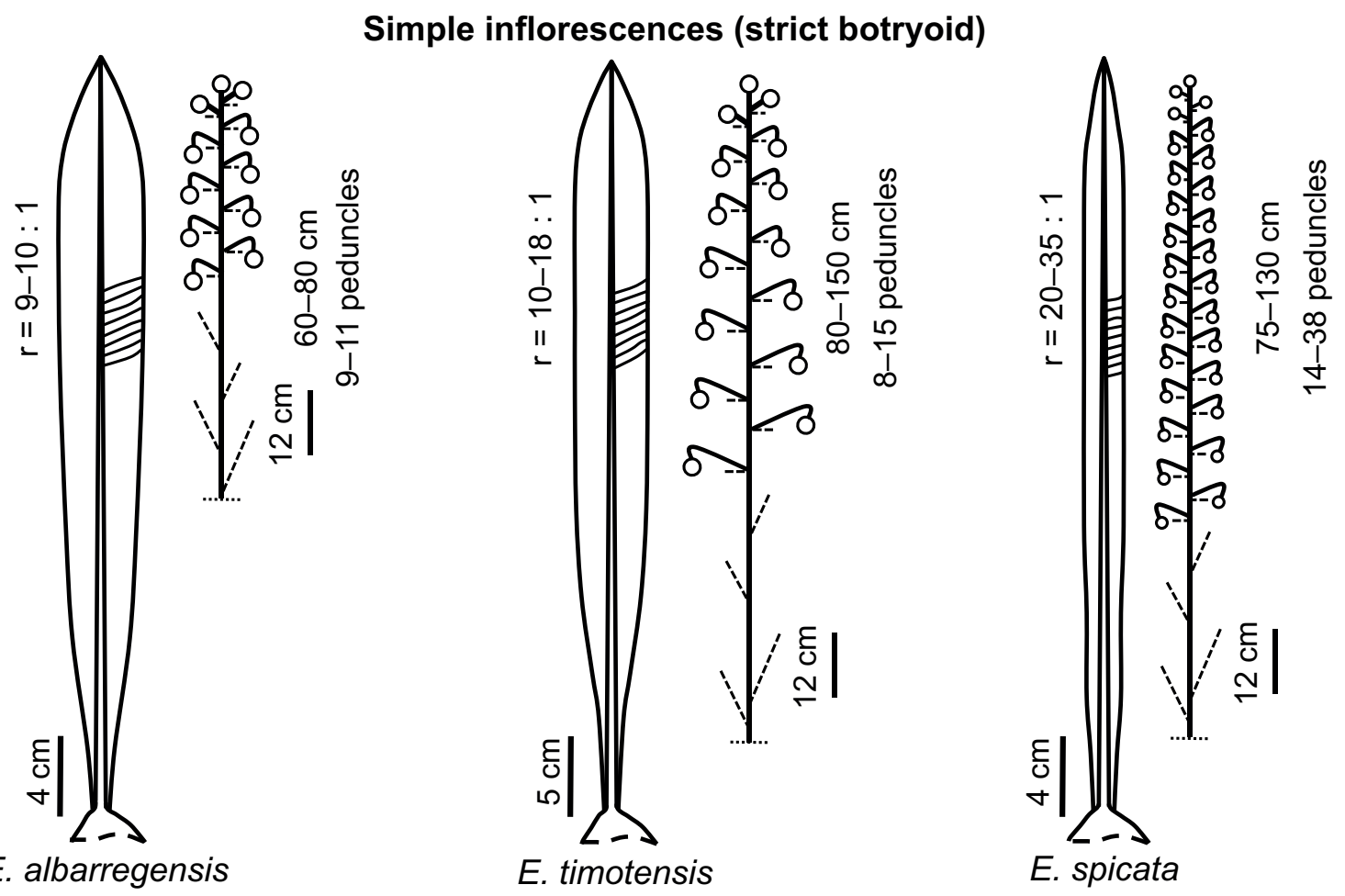

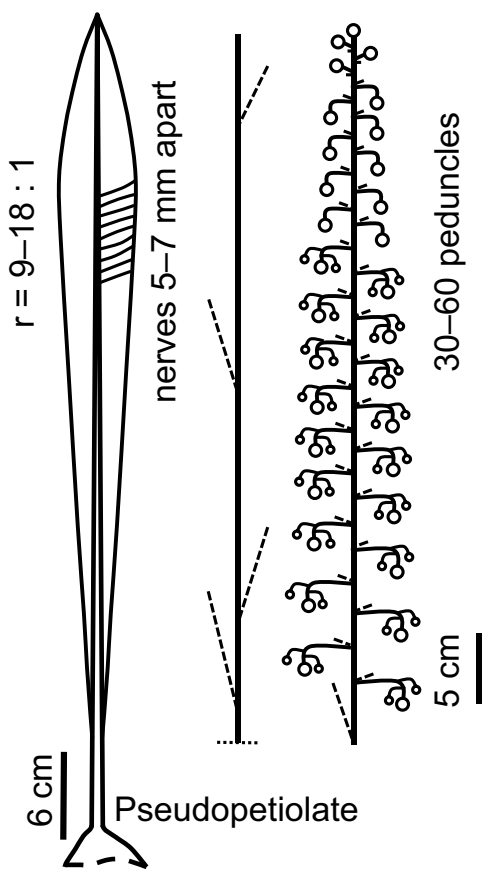

E. elongata

\section{Compound inflorescences}

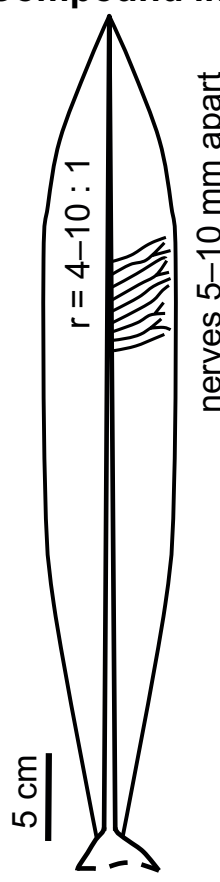

E. thyrsiformis

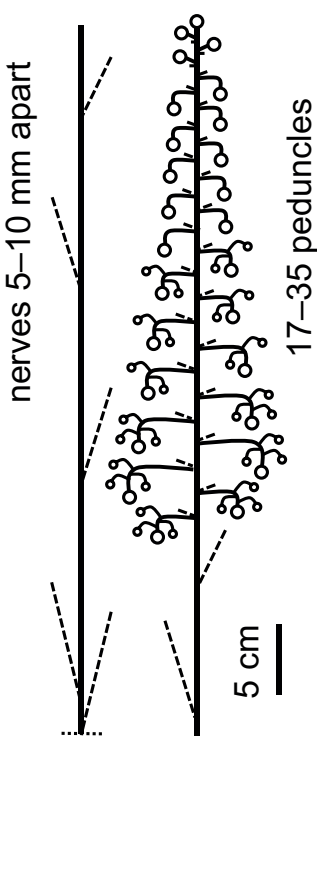

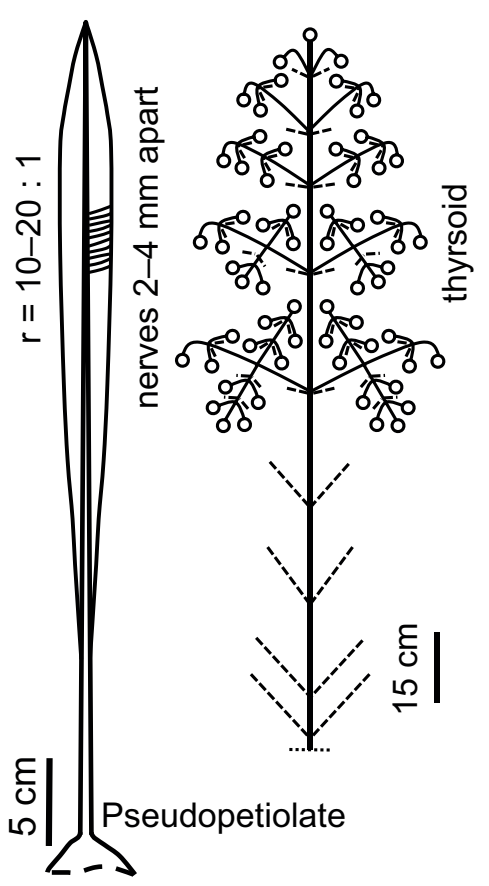

E. semiglobulata

$$
\text { . }
$$

